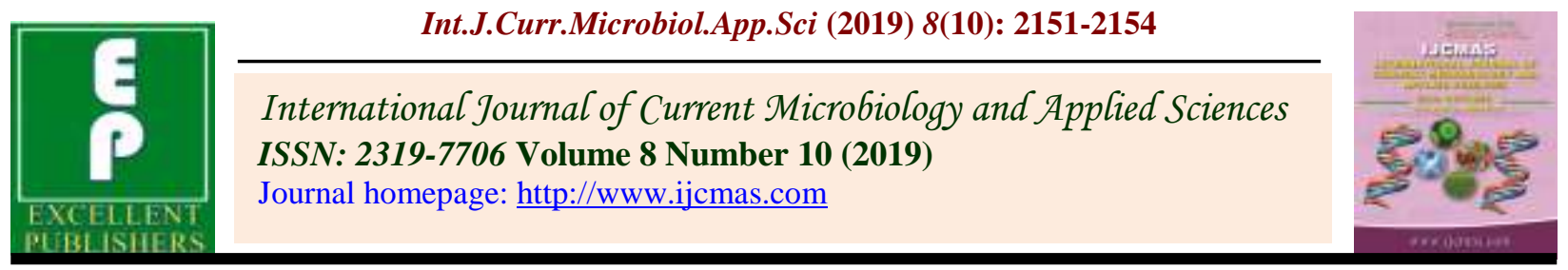

Original Research Article

https://doi.org/10.20546/ijcmas.2019.810.250

\title{
Effect of Sources and Levels of Zinc on Growth and Yield of Wheat (Triticum aestivum L.) in Loamy Sand
}

\author{
V. P. Al, Neha Chaudhary, S. R. Chaudhary* and D. G. Chaudhary
}

Department of Agricultural Chemistry and Soil Science, C. P. College of Agriculture, Sardarkrushinagar Dantiwada Agricultural University, Sardarkrushinagar, Gujarat, India

*Corresponding author

\section{A B S T R A C T}

\section{Keywords}

Growth, Yield, Zinc, Wheat

Article Info

Accepted:

15 September 2019

Available Online:

10 October 2019
In recent years the need for supplementation of zinc have been realized for maintaining animal and human health in addition to soil and plants. Efforts are under way to improve the food grain with zinc content through agronomic and genetic manipulation. Keeping in view an experiment was conducted at Agronomy Instructional Farm, Chimanbhai Patel College of Agriculture, Sardarkrushinagar Dantiwada Agricultural University, Sardarkrushinagar on effect of sources and levels of zinc on growth and yield of wheat (Triticum aestivum L.) in loamy sand during Rabi, 2014-2015. The soil of experimental plot was loamy sand in texture, low in both organic carbon and available nitrogen, medium in both available phosphorus and potassium and deficient in DTPA extractable zinc. In light of results obtain from this investigation, it is indicated that among sources the treatment $\mathrm{Zn}$-EDTA and in case of levels of zinc the treatment $\mathrm{Zn}_{3}\left(7.5 \mathrm{~kg} \mathrm{Zn} \mathrm{ha}{ }^{-1}\right)$ brought significant improvement in growth i.e. Number of effective tillers $/ \mathrm{m}$ row length, plant height, length of earhead, number of spikeletes / earhead, number of grains / earhead and yield attributes i.e. straw yield and grain yield over rest of the treatments.

\section{Introduction}

Wheat [Triticum aestivum (L.)] has been described as "King of cereals" and one of the most important staple food crop cultivated in 43 countries of the world. Wheat has its own outstanding importance as a human food; the nutritive value of wheat is fairly high as compared to other cereals. It contains 11.80,
$1.50,71.20,1.50,0.50,0.32$, percent protein, fat, carbohydrate, mineral matter, calcium and phosphorus, respectively (Swaminathan et al., 1981). Wheat (Triticum aestivum L. emend. Fiori \& Paol.) is the number one cereal of the world and being grown on the largest area. In India, wheat is the second most important food crop next to rice and it contributes nearly 35 per cent to the national food basket. Its 
contribution to the green revolution is significant. In India, Uttar Pradesh leads in area and total production, Punjab leads in productivity, (DWR, 2013). Zinc deficiency appears to be the most widespread and frequent micronutrient deficiency in crops and pasture of the crops lands were observed, resulting in severe losses in yield and nutritional quality. It is estimated that nearly half the soils on which cereals are grown have levels of available $\mathrm{Zn}$ low enough to cause $\mathrm{Zn}$ deficiency. Zinc as fertilizers can significantly enhance the yield and quality of crops. Severe Zn deficiency in the soil may cause yield losses up to 30 percent in cereal crops. Available zinc in Gujarat soils ranges between 0.25 to $2.58 \mathrm{mg} \mathrm{kg}^{-1}$ (Dangarwala et al., 1984). As nearly half of the Indian soil are $\mathrm{Zn}$ deficient and 24\% soils of Gujarat state are $\mathrm{Zn}$ deficient and 58\% soils of North Gujarat found deficient to medium in available $\mathrm{Zn}$ status. Zinc deficiency in agricultural soils affecting both yield and quality of crop.

\section{Materials and Methods}

The experiment was conducted on plot no. C-6 at the Agronomy Instructional Farm, Chimanbhai Patel College of Agriculture, Sardarkrushinagar Dantiwada Agricultural University, Sardarkrushinagar, District Banaskantha. The site is located at Northern part of Gujarat at the altitude of 154.52 meters above mean sea level, at $24^{\circ}-19^{\prime}$ North latitude and $72^{\circ}-19^{\prime}$ East longitude. The treatment comprised of four different sources of zinc as $\mathrm{S}_{1}$ - Zinc Sulphate $\left(\mathrm{ZnSO}_{4} \cdot 7 \mathrm{H}_{2} \mathrm{O}\right), \mathrm{S}_{2}$ - Zinc Chloride $\left(\mathrm{ZnCl}_{2} \cdot 2 \mathrm{H}_{2} \mathrm{O}\right), \mathrm{S}_{3}$ - Zinc Oxide (ZnO), $S_{4}-\mathrm{Zinc}$ EDTA and four levels of zinc as $\mathrm{Zn}_{0^{-}} 0.0 \mathrm{~kg} \mathrm{ha}^{-1}, \mathrm{Zn}_{1^{-}} 2.5 \mathrm{~kg} \mathrm{ha}^{-1}, \mathrm{Zn}_{2^{-}} 5.0$ $\mathrm{kg} \mathrm{ha}^{-1}$ and $\mathrm{Zn}_{3^{-}} 7.5 \mathrm{~kg} \mathrm{ha}^{-1}$. The soil of experimental plot was loamy sand in texture, low in both organic carbon and available nitrogen, medium in both available phosphorus and potassium and deficient in DTPA extractable zinc. The experiment was laid out in a Randomized Block Design with factorial concept (FRBD) in three replications. Wheat variety GW 322 was used as test crop. The data on growth and yield attributes were recorded from randomly selected five plants in each plot and seed yield and stover yield recorded from net plot and converted on hectare basis.

\section{Results and Discussion}

\section{Sources of Zinc}

Number of effective tillers/m row length, plant height, length of earhead, number of spikeletes / earhead, number of grains / earhead, straw yield and grain yield (Table 1) were significantly affected by treatment of different sources of zinc and these were rewarded significantly higher under application of $\mathrm{Zn}$ EDTA and was at par with zinc sulphate. The application of Zn-EDTA recorder highest growth and yield might be due to greater availability of zinc from Zn- EDTA as compared to other sources of zinc as in the deficient soil of experimental area. The results are in agreement with the findings of Das (2008) and Singh and Shivay (2015).

\section{Level of zinc}

Growth and yield parameters viz., number of effective tillers/m row length, plant height, length of earhead, number of spikeletes / earhead, number of grains / earhead, straw yield and grain yield (Table 1) were significantly affected by treatment of different level of zinc and these were significantly higher under treatment $\mathrm{Zn}_{3}: 7.5 \mathrm{~kg} \mathrm{ha}{ }^{-1}$ and was at par with $\mathrm{Zn}_{2}: 5.0 \mathrm{~kg} \mathrm{ha} \mathrm{h}^{-1}$. The application of treatment $\mathrm{Zn}_{3}: 7.5 \mathrm{~kg} \mathrm{ha}{ }^{-1}$ recorder highest growth and yield might be due to catalytic or stimulating effect of zinc on most of the physiological and metabolic processes of the plant. 
Table.1 Effect of sources and levels of zinc on number of effective tillers/m row length, plant height, length of ear head, number of spikelets / earhead and grain and straw yield of wheat

\begin{tabular}{|c|c|c|c|c|c|c|}
\hline \multirow[t]{2}{*}{ Treatments } & \multirow{2}{*}{$\begin{array}{c}\text { Number of } \\
\text { effective tillers/m } \\
\text { row length }\end{array}$} & \multirow{2}{*}{$\begin{array}{l}\text { Plant height } \\
\text { (cm) }\end{array}$} & \multirow{2}{*}{$\begin{array}{l}\text { Length of } \\
\text { earhead } \\
\text { (cm) }\end{array}$} & \multirow{2}{*}{$\begin{array}{c}\text { Number of } \\
\text { spikelets / } \\
\text { earhead }\end{array}$} & \multicolumn{2}{|c|}{ Yield (kg/ha) } \\
\hline & & & & & Grain & Straw \\
\hline \multicolumn{7}{|c|}{ Sources of zinc } \\
\hline $\mathrm{S}_{1}$ : Zinc sulphate $\left(\mathrm{ZnSO}_{4} .7 \mathrm{H}_{2} \mathrm{O}\right)$ & 84.19 & 85.63 & 8.74 & 16.03 & 4531 & 5664 \\
\hline $\mathrm{S}_{2}:$ Zinc chloride $\left(\mathrm{ZnCl}_{2} .2 \mathrm{H}_{2} \mathrm{O}\right)$ & 80.50 & 80.26 & 8.07 & 15.88 & 4170 & 5212 \\
\hline $\mathrm{S}_{3}:$ Zinc oxide $(\mathrm{ZnO})$ & 83.12 & 83.59 & 8.28 & 15.95 & 4318 & 5374 \\
\hline$S_{4}:$ Zinc EDTA (Zn-EDTA) & 87.81 & 89.64 & 8.91 & 16.20 & 4677 & 5829 \\
\hline S. Em. \pm & 1.75 & 2.19 & 0.21 & 0.44 & 118 & 148 \\
\hline C.D. at $5 \%$ & 5.05 & 6.33 & 0.60 & NS & 341 & 426 \\
\hline \multicolumn{7}{|c|}{ Levels of zinc } \\
\hline $\mathrm{Zn}_{0}: 0.0 \mathrm{~kg} \mathrm{ha}^{-1}$ & 80.07 & 78.91 & 7.91 & 15.33 & 4186 & 5219 \\
\hline $\mathrm{Zn}_{1}: 2.5 \mathrm{~kg} \mathrm{ha}^{-1}$ & 82.64 & 83.24 & 8.46 & 15.38 & 4336 & 5391 \\
\hline $\mathrm{Zn}_{2}: 5.0 \mathrm{~kg} \mathrm{ha}^{-1}$ & 85.53 & 86.96 & 8.76 & 16.34 & 4512 & 5656 \\
\hline $\mathrm{Zn}_{3}: 7.5 \mathrm{~kg} \mathrm{ha}^{-1}$ & 87.37 & 90.01 & 8.87 & 17.01 & 4662 & 5813 \\
\hline S.Em. \pm & 1.75 & 2.19 & 0.21 & 0.44 & 118 & 148 \\
\hline C.D. at $5 \%$ & 5.05 & 6.33 & 0.60 & 1.26 & 341 & 426 \\
\hline C.V. (\%) & 7.22 & 8.96 & 8.50 & 9.45 & 9.24 & 9.26 \\
\hline \multicolumn{7}{|c|}{ Interaction } \\
\hline Zn X S & NS & NS & NS & NS & NS & NS \\
\hline
\end{tabular}


Zinc also acts as a metal activator and it is an essential component of enzymes such as proteinase and peptidase which are responsible for assimilation of nitrogen. Zinc has also been reported to play an important role in regulating the auxin (IAA) concentration in plants. Thus, the application of zinc in zinc deficient soils $(<0.36 \mathrm{ppm})$ improved the growth and development of plant. The increase in yields might be due to an important function of zinc in bio-synthesis of indole acetic acid (IAA) and especially due to its role in initiation of promordia for reproductive parts and partioning of photosynthesis towards them, which resulted in better flowering and fruiting. The findings of present investigation are supported by Bathar and Patel (2005) and Keram et al., (2012).

In light of result obtain from this experiments, it is indicated that from Zinc source treatment $\mathrm{Zn}$-EDTA, while from $\mathrm{Zn}$ level treatment $\mathrm{Zn}_{3}$ $\left(7.5 \mathrm{~kg} \mathrm{Zn} \mathrm{ha}{ }^{-1}\right.$ ) brought significant improvement in growth and yield attributes of wheat.

\section{References}

Bathar, V.M. and Patel, P.T. (2005). Effect of zinc, fertility levels and FYM on growth and yield of wheat varieties under north Gujarat agro climatic conditions. GAU Res. J., Vol. 30 (1-2), pp.32-35

Dangarwala, R.T., Patel, K.P., George, V., Patel, K.C., Ramani, V.P. and Patel, M.S. (1994). Micronutrient and Sulphur Research in Gujarat. Bulletin page: 35

Das, K. and Guha, B. (1997). Effect of zinc, farm yard manure and fertilizer on rainfed wheat in Assam. J. Agric. Sci. Soc., N/E India 9 (2) 203-206

Directorate of Wheat Research (DWR), Annual report. 2013-14

Keram, K.S., Sharma, B.L. and Sawarkar, S.D. (2012). Impact of $\mathrm{Zn}$ application on yield, quality, nutrient uptake and soil fertility in medium deep black soil (Vertisol). International Journal of science, Environment and Technology, 1 (5): 563-571.

Singh, A., and Shivay, Y.S. (2015). Residual effect of summer green manure crops and zinc applied to rice (Oryza sativa) on succeeding durum wheat (Triticum durum) under basmati rice- wheat cropping sequence. Indian journal of Agronomy, 58 (3): 327-333.

Swaminathan, M., KanthaJoshephRao, N., Chandramani, S.V., Subramanyam, L. and Indira, K. (1981). Balanced diet and nutritive values of common recipes. $2^{\text {nd }}$ Feb., Sharda press, Mangalore.

\section{How to cite this article:}

Al, V. P., Neha Chaudhary, S. R. Chaudhary and Chaudhary, D. G. 2019. Effect of Sources and Levels of Zinc on Growth and Yield of Wheat (Triticum aestivum L.) in Loamy Sand. Int.J.Curr.Microbiol.App.Sci. 8(10): 2151-2154. doi: https://doi.org/10.20546/ijcmas.2019.810.250 